\title{
Hydrological Modeling of Large Drainage Basins Using a GIS-Based Hybrid Atmospheric and Terrestrial Water Balance (HATWAB) Model
}

\author{
Berhanu F. Alemaw \\ Department of Geology, Faculty of Science, University of Botswana, Gaborone, Botswana \\ Email: alemaw@mopipi.ub.bw, bfalemaw@gmail.com
}

Received March 26, 2012; revised April 27, 2012; accepted May 29, 2012

\begin{abstract}
A Hydrological model is proposed to study the spatial and temporal variability of the water budget components of large drainage basin systems from atmospheric and terrestrial water balances. In order to understand the water balances that include, surface runoff, actual evapotranspiration and soil moisture, a GIS-based simple water balance model which is referred as Hydrological Model from Hybrid Atmospheric and Terrestrial Water Balances with acronym HATWAB is presented. The spatio-temporal climatology database was created from a network of climate stations from CLIMWAT data base to reconstruct the monthly primary inputs to HATWAB model, rainfall and potential evapotranspiration. The modeling principles and HATWAB model are demonstrated using the Limpopo and Congo basins in Africa. The model was used to simulate water balance components by taking rainfall-runoff processes in the basin including soil-texture controlled moisture in the terrestrial system, and the vertical integrated moisture convergence that accounts for the net water vapor flux from the basins in order to close the hydrologic water budget.
\end{abstract}

Keywords: HATWAB; Water Budget; Large Drainage Basin; Soil Moisture; Vertical Integrated Moisture Convergence; Water Flux; GIS

\section{Introduction}

Hydrological modeling of large drainage basins is used to understand the complex hydrological processes that control the distribution and availability of hydrologic components and water resources availability in terms of atmospheric and terrestrial water balances. It is principally undertaken through precipitation partitioning into surface and groundwater flows, soil moisture and evapotranspiration. Spatial and temporal variations of regional water and energy balances over long and short time scales play an important role in changes in the stream flow of a basin. Precipitation being rainfall, evapotranspiration, runoff, percolation and soil moisture are the main components of the hydrologic cycle within semi arid regions. Their overall role to the hydrologic cycle are influenced by their interaction with soil, vegetation, topography and climate of the given area and to some extent by human interaction on the dry-land being crops, pastures and forestry.

Complex hydrologic systems have always been simplified in order to understand water balances within a catchment. To understand the spatial water balance components hydrological models have been employed for precipitation-runoff modeling based on GIS [1-3]. Among the most earlier catchment water balancing approach undertaken based on long term monthly climatic conditions was the one by [4], which then led to many researches on water balance models for similar conditions on a catchment, a region or a continental scale. Typical examples are 1) the USGS micro-computer Thornthwaite Water Balance model [5]; 2) a grid-based model for Latin America [6-8]; 3) a GIS-based water balance model at southern Africa scale [9]; 4) the Rhine flow model [10]; and 5) the large-scale water balance model for the upper Blue Nile in Ethiopia [11]. In South Africa, the Department of Water affairs and Forestry (DWAF) has developed a Water Balance Situation Assessment Model (WSAM) [12]. WSAM is widely used model in southern Africa to simulate streamflow, which allows calibration based on parameters for partitioning of precipitation into surface and subsurface components. The Famine Early Warning System Network (FEWS NET) hydrological model for the Limpopo basin [13], which is still under development, is one standard rainfall-runoff model that is expected to provide a continuous daily simulation of stream flow mainly developed for flood forecasting.

Increasing computer technology including use of GIS technique and physical (or quasi-physical) based hydro- 
logic modeling has become important in contemporary hydrology research for assessing the impact of human and/or possible climatic change on basin hydrology and water resources. This approach is widely used in the hydrologic research community compared to the systemstype black box models. Another advantage of physical or quasi-physical hydrological modeling is also its usefulness for investigating large-scale hydrological modeling thereby helping with planning, allocation and management of water resources.

In this manuscript results of a simplified water balance model, named Hydrological Model from Atmospheric and Terrestrial Water Balance (HATWAB) model [14], is presented and demonstrated for two basins, 1) the Limpopo river basin based on previously reported original data for the basin [15]; and 2) the Congo basin, based on previously presented data [16]. The model is capable of estimating monthly soil moisture, actual evapotranspiration, runoff and the vertical integrated moisture convergence. Such a model may be used for planning and decision support system in the region. HATWAB model was developed based on the approach proposed in [9], but was upgraded to cater for seasonal variation of vertically integrated moisture convergence $(C)$ as well as correcting the imbalances in the closure of the water budget which are catered for precisely to address a common challenge in water budget modelling at a basin scale. Perhaps this aspect remains one important contribution and attribute of this paper.

The major objective of this study was to understand the hydrological budget and processes in large drainage basins using HATWAB. The specific benefits of HATWAB and the objectives presented in this manuscript include: 1) determining the available spatial and temporal hydro-climatic information and data gaps to undertake water budget study, which is based on available sparse data; 2) mapping the spatial and temporal variability of rainfall, effective rainfall and potential evapotranspiration a basin scale; 3) assessing the spatial and temporal variability basin water budget in terms of soil moisture, actual evapotranspiration, runoff, and vertically integrated moisture convergence.

By doing so a number applications of HATWAB can be sought that include mainly: 1) Assessment of water availability and distribution in a drainage basin; and 2) Assessment of climate change and large scale humaninduced changes.

\section{Approach and Methodology}

\section{Selecting a Template}

The modeling approach followed was based on parameterizations to compute temporal and spatial variability of water budgets at geo-referenced grid cells covering a drainage basin. The model computes the integrated moisture convergence $(C)$ and soil moisture in solving the water budgets in the atmospheric and terrestrial components, respectively. Uncertainties on atmospheric water balance estimates and imbalances are also investigated.

The atmospheric component of the water balance is expressed as follows [14]:

$$
\mathrm{d} W / \mathrm{d} t=-P+E+C
$$

where $\mathrm{d} W / \mathrm{d} t$ is the storage change (LT-1). $C$ is the vertical integrated moisture convergence (LT-1) and was expressed as a function of a variable $Q$ which is the water vapour flux (LT-1), as follows:

$$
C=-\nabla \times Q
$$

The storage change, $\mathrm{d} W / \mathrm{d} t$ is usually ignored because changes in precipitable water are quite small in averages over time scales of a month or more [8]. Then Equation (1) reduces to

$$
P-E=C
$$

The terrestrial water balance model on a monthly time scale can be written as

$$
\mathrm{d} S / \mathrm{d} t=P-E-R
$$

where $S$ is soil moisture storage (L); $P$ is precipitation (LT-1); $E$ is actual evapotranspiration (LT-1); and $R$ is the observed runoff (LT-1). The monthly $E$ can be calculated once the soil moisture is determined. Then by combining Equations (3) and (4), it follows that the vertical integrated moisture convergence, $C$ is computed as:

$$
C=\mathrm{d} S / \mathrm{d} t+R
$$

In a steady state $P-E=R$. Changes in storage could however lead to $P-E$ being different from $R$. These could also be due to certain errors in representing rainfall within a basin under consideration. These lead to the expression of an imbalance equation

$$
I_{m b}=\frac{C-(\mathrm{d} S / \mathrm{d} t+R)}{R}=\frac{C}{R}-\frac{\mathrm{d} S / \mathrm{d} t}{R}+1
$$

Contrary to the formulation adopted in this study based on Equation (6), [8] assumed that $\mathrm{d} S / \mathrm{d} t$ is negligible for monthly time scales and applied it to the Amazon basin, which reported unaccounted residuals in water budgets. Whereas in the proposed model in this study, the soil moisture variation $\mathrm{d} S / \mathrm{d} t$ is varying from season to season as a function of the prevailing $E p$ and $P$ at a given location according to Equation (4), in which the imbalance should also cater for this variability according to Equation (6). One of the contributions of this study is that, once the imbalance (Equation (6)) is kept to a minimum in the water balance computation at each grid, then the simulated variables and water balances, $P, E, R$, $R / P, E-P, E / E p, S$ and $C$ can then be used to investigate 
the seasonal and temporal variability of a basin's water budget.

The amount of precipitation and potential evapotranspiration determine soil moisture availability, which in turn is controlled by the water holding capacity of the soils. Solution of the mass balance equation was solved for $\mathrm{E}, \mathrm{R}$ and $\mathrm{S}$ based on procedures given in $[6,9,17]$.

\section{The Study Area and Data}

The study area considered, the Limpopo river basin and the Congo basin, are two of the major drainage systems in Africa (Figure 1) with huge interest for regional development among the riparian states. The Limpopo basin represents predominately arid to semi arid regions with low rainfall regimes where as Congo basin predominately represents high rainfall regimes.

In order to solve the water budget equations and cover the study area with the minimum available information and effort, gauged data from the FAO CLIMWAT database [18] within each basin was resampled and used. A total of 66 stations in Limpopo and 145 stations in the Congo basin were used in the analysis. The extracted data was based on a rectangular region in which the basins are located. The data includes long-term average monthly rainfall, effective rainfall $(P e), E p$ and other climatic variable such as temperature (minimum, mean and maximum), wind speed, sunshine hours and solar radiation. The point distributed hydroclimatic data were spatially interpolated using the Inverse distance squared (IDS) method.

One of the main inputs required in the proposed water balance model is the effective precipitation $(P e)$. At a monthly time scale, the effective precipitation is calculated as per the formula of the USDA soil conservation available from FAO manual [20]. The reference evapotranspiration $(E o)$ is computed according to the FAO's Penman-Monteith method [20]. These soil textural classes have been extracted from agronomical soil classes of soils databases of FAO/UNESCO [21] according to the methodology proposed in [9]. The soils data were originally available at 10 minutes spatial resolution, which was further regridded using pixel thinning algorithm [22]. From textural reclassification of soils and vegetation cover data (based on the NDVI imagery data of 1987), soil-water retention parameters such as field capacity (FC), wilting point (WP) and available moisture content (AMC) values were extracted at each grid cell was within the basin according to soil-water relations [9,23]. All the spatial data were compiled in a GIS raster grid format at a spatial resolution of 5' by 5' (9.2 km by $9.2 \mathrm{~km})$ representing the study basins.

\section{Analysis of Results and Discussions}

For a single geographically referenced grid cell, the model is run independently for the simulation period of 30-years to derive a basin-wide map of water balances. The water balances were conducted for a period of 30 years assuming that the mean does not change during this normal period. This was important as 30 years is the mean record length of the data obtained from CLIMWAT database [18], which represents the rainfall and other climatic variables. In each simulation year, the model

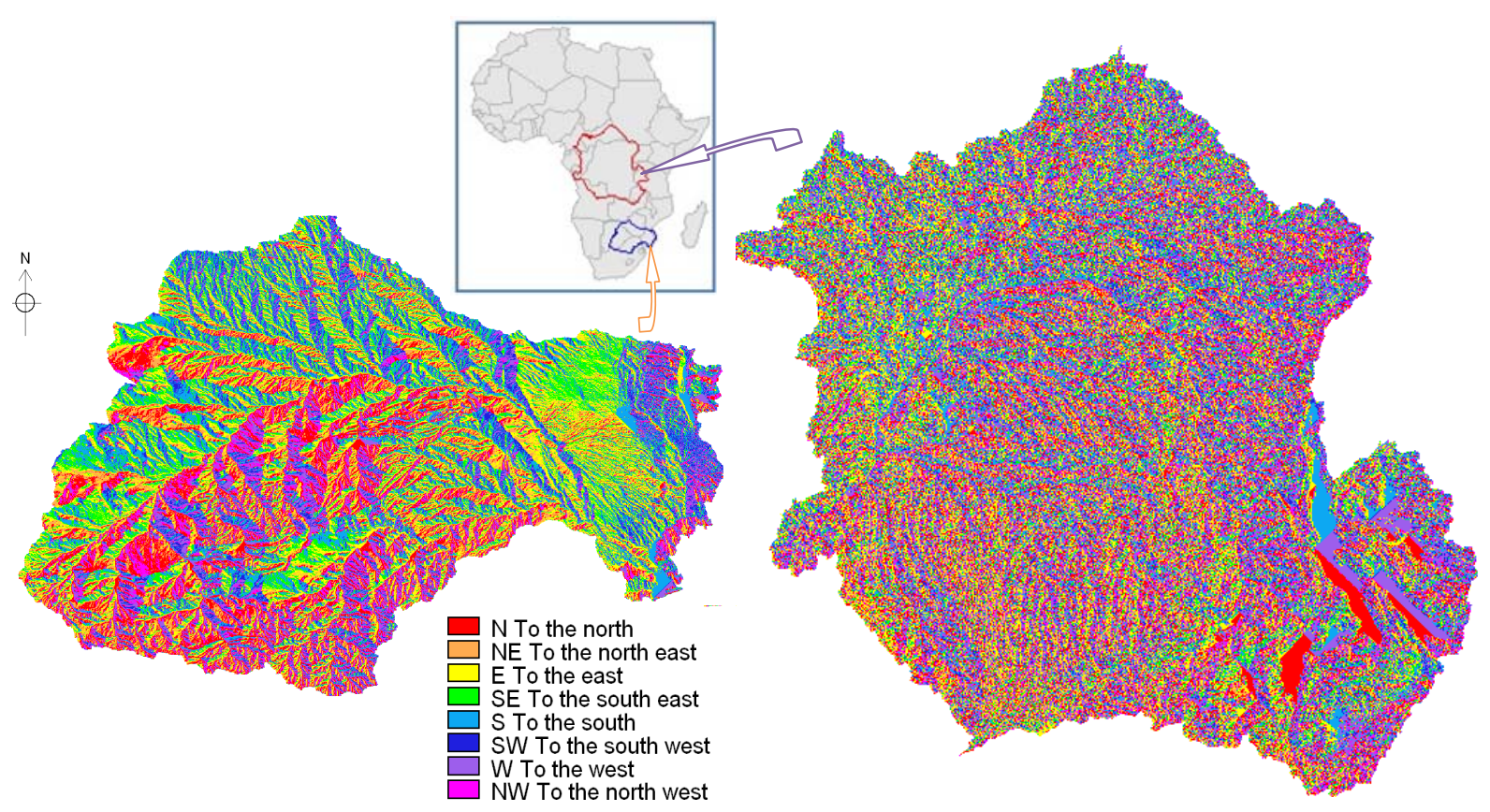

Figure 1. Location map of the Limpopo and Congo basins and flow direction grid maps (own Figures: [16,19], modified). 
in the soil moisture zone is run for a time loop of 12 months, by applying the $P$ and $E p$. If a dynamic state is not achieved in soil moisture storage term $(S)$, actual evapotranspiration $(E)$ and runoff $(R)$ between subsequent simulations, the simulation proceeds until a dynamic steady state is achieved within $0.01 \%$ error in all of these variables. When the steady state situation is arrived, the outputs $S, E$ and $R$ are maintained, and the spatial control module is invoked and computation for another grid cell continues.

The model is then applied for all grids that represent the basin under consideration according to the spatial identifier of such grids.

Computation of monthly water balances throughout all the identified grids with each basin has been undertaken, and results for geo-referenced grids in the each basin have been stored in the results database. The actual evaporation which was computed from the mass-balance equations, whose value as a ratio to its potential value, $E p$ is assumed to change linearly with the soil moisture storage for the given month that satisfies Equation (4). For each grid, the soil moisture was computed on a monthly basis in such a way that closure of the water budget is achieved as stipulated by mass balance equations (Equation (4)) until close of the hydrological budget is achieved.

Typical variations of temporal/seasonal water balances at selected grids is shown in Figure 2(a) and Figure 2(b) for grid cells centered on $29.03^{\circ} \mathrm{E} / 19.93^{\circ} \mathrm{S}$ and $29.12^{\circ} \mathrm{E} /$ $26.33^{\circ} \mathrm{S}$, respectively. A common feature of all the seasonal portrayals of these water balances components is that the actual $E$ values are less than the $E p$ values for any given month, which is as expected. The same applies between the rainfall and generated runoff.

The reference evapotranspiration $(E p)$ computed based on the FAO Penman-Monteith method [20] at 66 climate stations in the Limpopo basin and 145 climate stations in the Congo basin, which were further resampled at the corresponding pixels in the same format as the other spatial information. For Limpopo basin, the annual Ep values reach above $1100 \mathrm{~mm}$ with almost $50 \%$ of the basin having higher values ranging from 600 to $900 \mathrm{~mm}$. Soil moisture is found to range between 50 and $450 \mathrm{~mm}$ with most of the area dominated with higher moisture ranges.

The actual evapotranspiration computed for the Limpopo Basin using the developed water balance model is shown in Figure 3. The actual evapotranspiration is found to be varying within the entire basin. The $\mathrm{E}$ varies from 400 to $1100 \mathrm{~mm}$ per year with most of the basin, accounting about $60 \%$ of the basin area having the highest E.

For the Congo basin, the simulated annual total runoff in relation to precipitation is shown in Figure 4. The mean annual Runoff for the Congo basin varies between
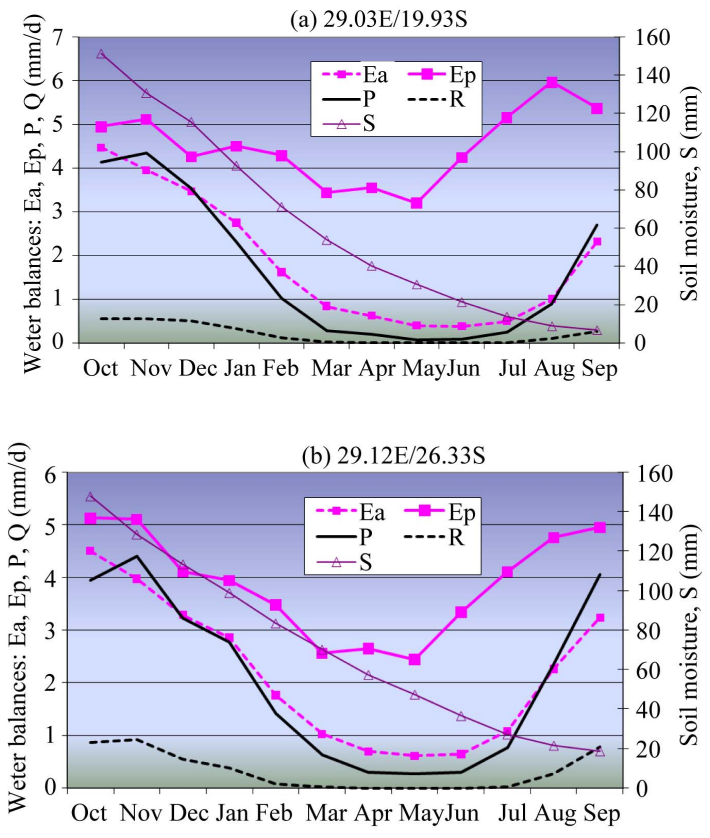

Figure 2. Temporal variation of water balance components computed in the Limpopo basin at a grid cell centered on (a) $29.03^{\circ} \mathrm{E} / 19.93^{\circ} \mathrm{S}$ and (b) $29.12^{\circ} \mathrm{E} / 26.33^{\circ} \mathrm{S}$ (own figure, modified from [15]).

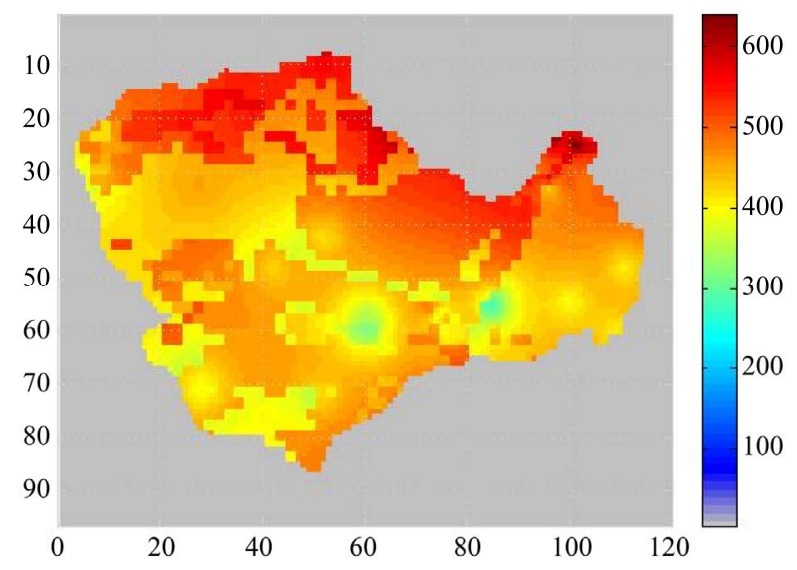

Figure 3. Annual actual evapotranspiration variation in the Limpopo basin (mm).

1 and $1945 \mathrm{~mm}$ with a mean annual runoff of $342 \mathrm{~mm}$. The annual simulated runoff show a general trend strongly influenced by the distribution pattern of precipitation. The highest values are concentrated in the heart of the equatorial forest along the Middle Congo river branch. This area records higher rainfalls in the whole basin. The lowest value is simulated in the southern hemisphere around the grid of coordinate $31^{\circ} \mathrm{E}$ and $6.73^{\circ} \mathrm{S}$ (western part of Tanzania). A part the lakes, the highest values of runoff are simulated in the heart of the equatorial forest across the equator, and decrease progressively towards the tropics. This trend is relatively disturbed with the soil 


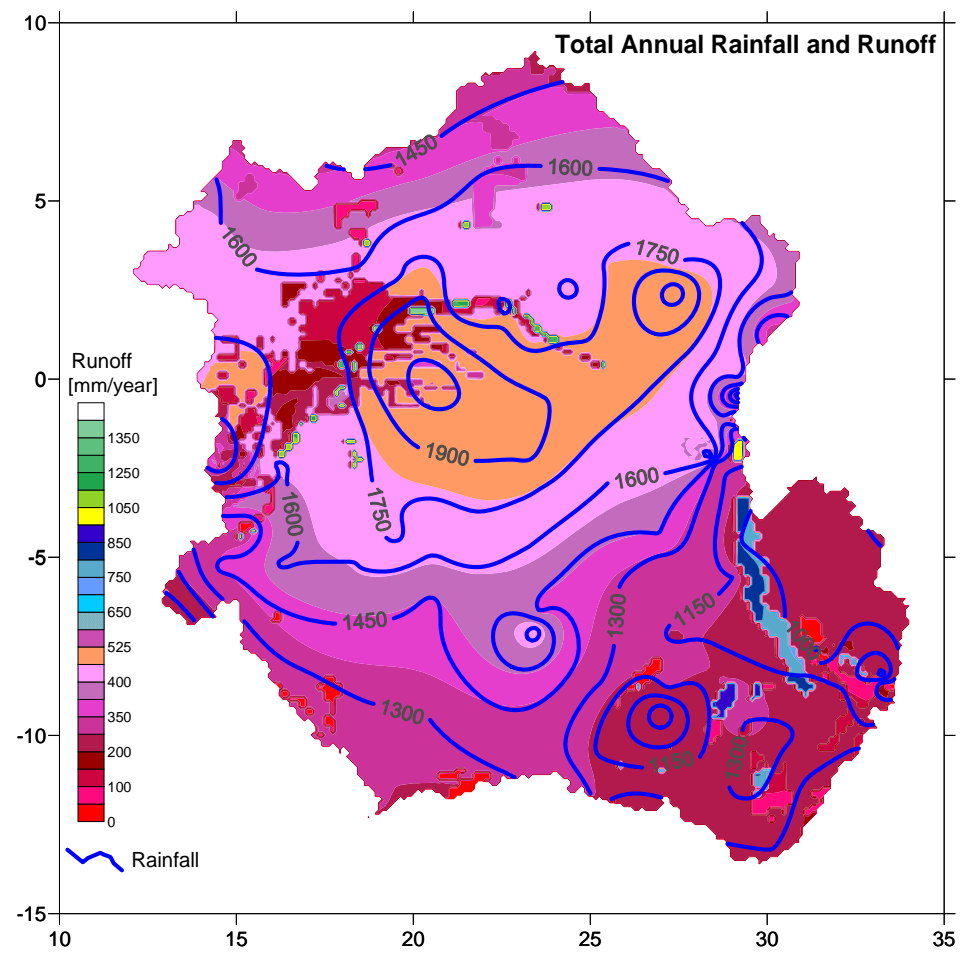

Figure 4. The simulated runoff and areal precipitation in the Congo river basin.

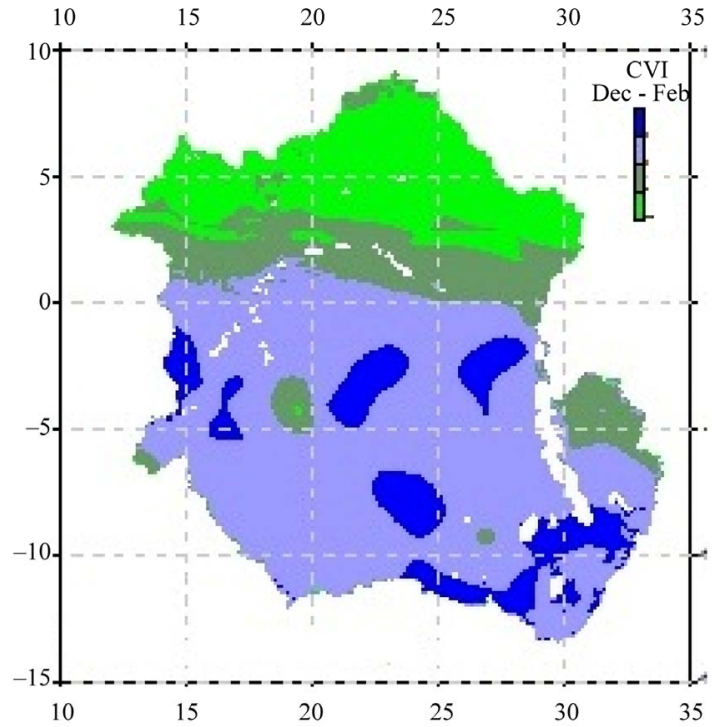

(a)

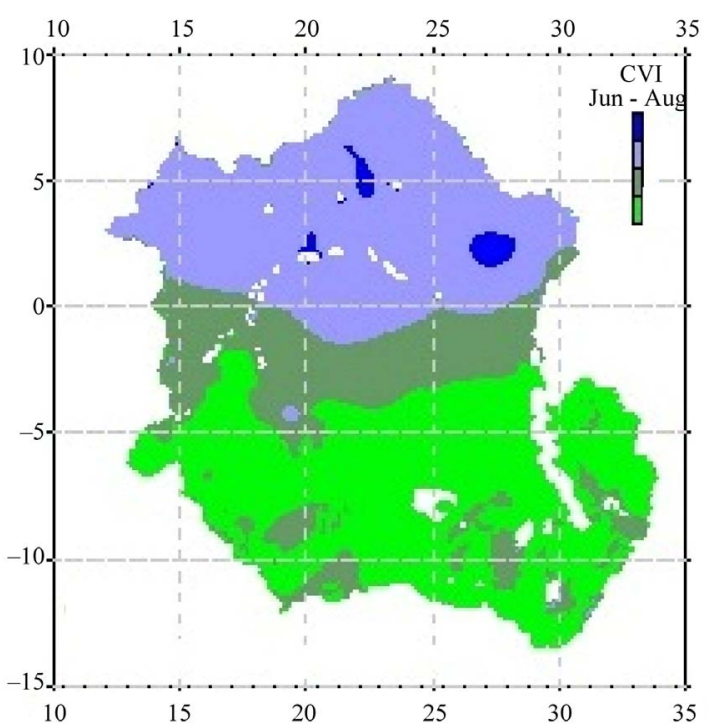

(b)

Figure 5. The simulated vertically integrated moisture convergence $C$ in the Congo river basin (a) Dec to Feb (left); (b) Jun to Aug (right) (Source: Own data, [16]).

types especially in the south-eastern, the extreme north region and along the main Congo River.

The corresponding grid-based vertical integrated the moisture convergence $(C)$ computed during water balance calculations for the Congo basin are shown in Figure 5. The moisture convergence corresponds to the negative values whereas the positive values correspond to the moisture divergence. This clearly is displayed in the see-saw fluctuation of $C$ between the above and below equator during the different quarters, winter and summer occurring in the two climatic regimes of the basin.

\section{Summary}

HATWAB, though simple in form and easy to implement with Fortran, it can be used to solve and answer basin 
water resources planning questions of determining water resources availability and distribution at a basin level with localized various spatial and temporal scales depending on the need.

The changes in the input climatic Changes variables such as precipitation and potential ET can easily be incorporated in the model structure in order to simulate the effect on runoff under climate change scenarios. Effects of land cover and land use change as a result of human activity can be considered in HATWAB.

As the grid water balance computations are compatible with raster GIS platforms, the extended application of HATWAB model for hydro-morphologic parameters that control surface runoff can be explored.

However, the model, even if it is at its early stage of development, it is potentially suitable to incorporate human induced changes such as land use land cover and climate impacts in the rainfall-runoff processes of and integrated water resources management of large drainage basins. It is also possible to study transboundary interests in joint management of shared water resources especially in data scarce Africa where this gap is overcome by the approach presented in this manuscript.

\section{Acknowledgements}

The author appreciates the support of the University of Botswana, Department of Meteorological Services, the NUFU project (NUFUPRO-2007/10079) and the Challenge Programme on Water and Food (CPWF). The University of Dar es Salaam is also appreciated which mentored and hosted a PhD research of the author back in the late 1990s, from which some of the concepts of this manuscript were developed, applied and tested.

\section{REFERENCES}

[1] M. R. Knebl, Z. L. Yang, K. Hutchison and D. R. Maidment, "Regional Scale Flood Modeling Using NEXRAD Rainfall, GIS, and HEC-HMS/RAS: A Case Study for the San Antonio River Basin Summer 2002 Storm Event,” Journal of Environmental Management, Vol. 75, 2005, pp. 325-336. doi:10.1016/j.jenvman.2004.11.024

[2] G. H. Leavesley, S. L. Markstrom and R. J. Viger, "USGS Modular Modeling (MMS)-Precipitation-Runoff Modeling System (PRMS),” In: V. P. Singh and D. K. Frevert, Eds., Watershed Models, Taylor and Francis, Boca Raton, 2006.

[3] W. T. Lin, W. C. Chou, C. Y. Lin, P. H. Huang and J. S. Tsai, "WinBasin: Using Improved Algorithms and the GIS Technique for Automated Watershed Modelling Analysis from Digital Elevation Models,” International Journal of Geographical Information Science, Vol. 22, No. 1, 2008, pp. 47-69. doi:10.1080/13658810701300121

[4] C. W. Thornthwaite and J. R. Mather, "Instructions and
Tables for Computing Potential Evapotranspiration and the Water Balance,” Drexel Institute of Technology, Publications in Climatology, X(3), USA, 1957.

[5] G. J. McCabe and S. L. Markstrom, "A Monthly WaterBalance Model Driven by a Graphical User Interface,” U.S. Geological Survey Open-File Report 1088, 2007, pp. 1-6.

[6] C. J. Vorosmarty, B. More, A. L. Grace, M. P. Gildea, J. M. Melillo, B. J. Peterson, E. B. Rasteller and P. A. Steudler, "A Continental Scale Models of Water Balance and Fluvial Transport: An Application to South America,” Global BioGeochemical Cycles, Vol. 3, No. 3, 1989, pp. 241-265. doi:10.1029/GB003i003p00241

[7] N. Zeng, "Seasonal Cycle and Interannual Variability in the Amazon Hydrologic Cycle,” Journal of Geophysical Research, Vol. 104, 1999, pp. 9097-9106. doi:10.1029/1998JD200088

[8] J. A. Marengo, "Characteristics and Spatio-Temporal Variability of the Amazon River Basin Water Budget," Climate Dynamics, Vol. 24, 2005, pp. 11-22. doi: 10.1007/s00382-004-0461-6

[9] B. F. Alemaw and T. R. Chaoka, "A Continental Scale Water Balance Model: A GIS-Approach for Southern Africa," Journal of Physics and Chemistry of the Earth, Vol. 28, No. 20-27, 2003, pp. 957-966.

[10] W. P. A. Van Deursch and J. C. J. Kwadijk, "An Integrated GIS Water Balance Model for the River Rhine," Proceeding of Viena Conference, IAHS Publ., the Netherlands, No. 211, 1993, pp. 507-518.

[11] D. Conway, “A Water Balance Model of the Upper Blue Nile in Ethiopia,” Hydrological Science Journal, Vol. 42, No. 2, 1997, pp. 265-286. doi:10.1080/02626669709492024

[12] DWAF, Department of Water Affairs and Forestry, Republic of South Africa, "Water Balance Situation Assessment Model (WSAM),” 2007. http://www. Iusersupport.co.za/

[13] USGS, "Interactive Stream Flow Model, Flood Risk Map and Hydrographs,"

http://edcw2ks40.cr.usgs.gov/sa_floods/article.asp?sid=3 $7 \&$ comm=yes

[14] B. F. Alemaw, "A Hybrid Atmospheric and Terre-Strial Water Balance Model. A GIS Based Approach for Large Drainage Basins,” Internal Research Report, University of Botswana, 2006, p. 32.

[15] B. F. Alemaw, T. R. Chaoka and O. Matenge, "Spatial and Temporal Variability of the Limpopo River Basin Water Budget from a GIS-Based Limpopo Water Balance Model,” In: Savenije, et al., Eds., CD-ROM Proceedings of Water-Net/Warfsa/GWP-SA Annual Symposium, Lilongwe, Malawi, 1-3 November 2006.

[16] J. B. Chishugi and B. F. Alemaw, "The Hydrology of the Congo River Basin: A GIS-Based Hydrological Water Balance Model," In: S. Starrett, Ed., Proceedings of World Environmental and Water Resources Congress 2009 (American Society of Civil Engineers): Great Rivers, Kansas City, 17-21 May 2009, pp. 1-16.

[17] B. F. Alemaw, "Development and Application of a GIS- 
Based Regional Hydrological Variability and Impact Assessment System for the Southern African Region,” PhD Thesis (unpub.), University of Dar es Salaam, 1999, pp. $1-282$.

[18] Food and Agriculture Organisation (FAO), FAO CLIMWAT for CROPWAT, CD-ROM. Agroclimatic Database. Rainfall and Evaporation Figures, United Nations Food and Agriculture Organization (FAO), World Reference Base for Soils, Rome, 2003.

[19] B. F. Alemaw, "Flood Hazard Forecasting and Geospatial Determinants of Hydromorphology in the Limpopo Basin, Southern Africa,” Journal of Disaster Advances, Vol. 3, No. 4, 2010, pp. 571-581.
[20] R. G. Allen, L. S. Pereira, D. Raes and M. Smith, “Crop Evapotranspiration-Guidelines for Computing Crop Water Requirements,” FAO Irrigation and drainage paper 56, Food and Agriculture Organization, Rome, 1988.

[21] FAO, "An Explanatory Notes on the FAO World Soil Reference Map,” World Soils Resources Report, No. 66, 1988.

[22] J. R. Eastman, "Guide to GIS and Image Processing", IDRISI32, Release 2, Vol. 1, Manual Version 32.20. 2001, pp. 1-161.

[23] Clark University, Graduate School of Geography, Worcester, Massachusetts, 1997. 